\title{
Renal Pelvis and Ureter Cancer pTX TNM
} Finding $v 7$

National Cancer Institute

\section{Source}

National Cancer Institute. Renal Pelvis and Ureter Cancer PTX TNM Finding v7. NCI

Thesaurus. Code C89307.

Renal pelvis and ureter cancer in which the primary tumor cannot be assessed. (from AJCC 7th Ed.) 